\title{
Nadežda Čačinovič
}

Neizbježni

materijalizam estetike 


\section{Nekoliko napomena}

Tvrdnja iz naslova mnogima će se učiniti sama po sebi razumljivom, nikako ne nečim što bi trebalo posebno dokazivati. Kako sama riječ nameće, estetika kao riječ svojim porijeklom implicira osjetilnu percepciju. No time postaje i jedno od posebno istaknutih poprišta konstruiranja binarne opozicije idealizma i materijalizma. U brojnim varijantama estetičkih teorija postulira se tek osjetilno pojavljivanje nečeg nad ili ne-osjetilnoga.

U posljednjem desetljeću, a i nešto duže, ta se problematika među "kontinentalnim" estetičarima (institucionalno legitimiranim u akademskom pogonu) često raspravlja vezano uz sintagmu "podjela osjetilnoga" Jacquesa Rancièrea pa će i ovo izlaganje tako započeti. U "prizorima iz estetičkoga režima umjetnosti”, kako glasi podnaslov Rancièreove knjige Aisthesis, čitamo:

"Na Zapadu je tijekom dva stoljeća 'estetika' bila ime kategorije kojom se označavala osjetilna sazdanost i inteligibilna forma onoga što nazivamo ‘Umjetnošću'. Već sam u svojim ranijim djelima imao priliku iznijeti argumente kako, bez obzira na to što povijesti umjetnosti započinju svoje narative s jamskim slikarijama s početka vremena, Umjetnost kao pojam koji obilježava formu specifičnog iskustva postoji jedino na Zapadu negdje od kraja osamnaestoga stoljeća. Prije toga su, naravno, postojale svake vrste umjetnosti i prakse, a mali broj njih je uživao privilegirani status, ne zahvaljujući intrinzičnoj izvrsnosti nego svojemu mjestu u podjeli socijalnih uvjeta. Lijepe umjetnosti bile su izdanak takozvanih slobodnih umijeća. Ta su se razlikovala od mehaničkih zato što su se njima bavili slobodni ljudi, dokoni, koje je njihova vrsnoća upravo priječila da traže preveliko savršenstvo u materijalnoj izvedbi, kakvo bi mogao postići neki obrtnik ili rob. Umjetnost kao takva počela je postojati na Zapadu kada se hijerarhija formi života počela urušavati. Uvjeti toga pojavljivanja ne mogu se izvesti iz nekog općeg pojma umjetnosti ili ljepote zasnovanog na općoj teoriji čovjeka ili svijeta, subjekta i postojanja. Takvi pojmovi i sami ovise o transformaciji formi osjetilnoga iskustva, načina percipiranja, načina aficiranosti. Oblikuju modus inteligibilnosti iz tih rekonfiguracija iskustva." ${ }^{01}$

Rancière time nastavlja na poznate uvide o povijesnosti pojma umjetnosti i uvjetima nastanka po samorazumijevanju autonomne um-

01 Jacques Rancière, Aisthesis, Galilèe, Pariz 2011, str. 9. 
jetnosti potankim istraživanjem iskustvenih, osjetilnih pretpostavki. Razvija realizam uvjeta, a ne realizam mimeze. Za njega je, posve eksplicitno formulirano, socijalna revolucija moguća samo kao plod estetičke revolucije. Ne zato što bi se umjetničkim djelima posebno dobro prenosile istine, spoznaje ili moralne pouke, već zato što je imaginiranje alternative vezano uz mogućnost preokreta osjetilnoga i afektivnoga poretka.

Rancière traži mjesta obrata mimo uobičajenog izlaganja vrhunaca tzv. Umjetnosti u razdoblju estetičkoga režima. Počinje tek prividno konvencionalno s Winckelmannom, a već analiza ulomka iz Hegelovih predavanja o estetici, posvećenog detalju jedne Murillove slike, pokazuje što namjerava: izložiti čitavu interpretativnu mrežu koja nastaje nekim singularnim događajem ili tekstom. Slijedi poglavlje o kritičkoj recepciji Stendhalovog romana Crveno i crno, o skandalu izazvanom na kraju tog romana, u kojemu Julien Sorel nalazi sreću čekajući smrt, zato što je u tim danima izvan složene mreže planova, voljnog faktora, nadilaženja okvira porijekla. Slijedi analiza jednog Emersonovog predavanja iz 1844. godine pa analiza prikaza što ga je francuski pjesnik Théodore de Banville napisao o predstavi engleskih klaunova Hanlon Lee Brothers. Pa onda tekst Mallarméa iz 1893. o nastupu Loie Fuller i Maeterlinckova kritika nove izvedbe Ibsenovog Graditelja Solnessa iz 1894. Slijedi predavanje Rogera Marxa o dizajnerskom umijeću Emilea Galléa održano radnicima. Rilkeovo pisanje o Rodinu, iz 1902. u usporedbi s time dobro je poznato, pa i inovativnost Edwarda Gordona Craiga koji 19o8. piše o scenografiji. Viktor Šklovski je 1916. pisao o Charlieu Chaplinu a Paul Rosenfeld 1921. o fotografijama Alfreda Stieglietza. Slijede još Dziga Vertov i James Agee.

Rancière svoja detaljna proučavanja izlaže na način koji je jedan recenzent knjige nazvao "slobodnim indirektnim stilom", izrazom koji se inače koristi za tzv. lijepu književnost ali koji Rancièreu omogućuje narativni kontinuitet uz maksimalni pristup složenom, arhivistički precizno proučenom materijalu. Zapravo, i u ovoj knjizi Rancière ostaje u poziciji učitelja neznalice čije majstorstvo je u tome da postavlja pitanja na koje učenici sami pronalaze odgovore. To ne samo da ukida razlike između visoke i pučke razine kulture i poziciju autoriteta nego omogućuje Rancièreu produbljivanje uvida u estetički režim - materijalizam nije samo deklarativan nego demonstriran u shvaćanju različitih vrsta osjetilnosti i tjelesnosti.

Prije gotovo pola stoljeća jedan drugi projekt, Adornova Estetička teorija, nastojala je uključiti i kritički preispitati klupko osjetilnoga i 
nadosjetilnoga koje je određivalo govor o umjetničkim djelima, filozofiju umjetnosti i na kraju estetiku. Materijalizam je trebala zastupati dosljedna svijest o neidentičnome, duh odvojen u svrhu samoodržanja, a u nastavku na znamenitu rečenicu s početka Negativne dijalektike: "Filozofija koja se jednog trenutka činila nadiđenom, održava se na životu jer je trenutak njezinog ozbiljenja bio propušten.” ${ }^{02}$

Ta jedna rečenica odmah prekida takoreći iznutra s tradicijom hegelovsko-marksističkog očekivanja nužnog i neumitnoga prevrata, u negaciji negacije, određenoj negaciji, konstrukciji svjetsko-povijesnoga zbivanja. Ne prekida s dijalektikom: s "dijalektikom kao konsekventnom svijesti o neidentičnosti". "Rano" djelo, Dijalektika prosvjetiteljstva, bilo je preispitivanje svakog, pa i vlastitog povjerenja u napredovanje spoznaje. Izvor racionalnosti, tu je dijalektika obrat koji se očituje u tomu da je povijest ovladavanja prirodom ujedno i povijest ugnjetavanja čovjeka čovjekom, da odnos mitskog i prosvijećenog mišljenja nije naprosto napredovanje, da je već mit prosvjetiteljski napor, a prosvjetiteljstvo mit.

Adorno ističe prioritet objekta koji može biti mišljen samo kroz subjekt, dostupan je samo subjektivnoj refleksiji, no nasuprot subjektu uvijek se održava kao ono drugo. Mišljenje je i u nastanku i u djelovanju povezano s patnjom samo-održavanja, ali i s obećanjem slobode, obećanjem pomirenja, kao dokidanja besmislene patnje. Snagom subjekta valja dokinuti privid konstitutivne subjektivnosti, sredstvima logike konzekvencije slomiti nadmoćnost logike, prinudu identičnosti.

Važna i klasicima bliska je sljedeća rečenica: “Ideologija nije nešto što prekriva društveni bitak kao sloj koji se može ukloniti, nego je sadržana u njemu. Utemeljena je u apstrakciji koja je bitna sastavnica razmjenskog odnosa”.

Nakon toga pojavljuje se, već posthumno, Estetička teorija. Umjetnost izmiče definiciji, ali ne i refleksiji. Osnovno je njezina dvostrukost, to da je istovremeno i društvena činjenica i autonomna. Odustajanje od autonomije, bilo u takozvanom angažiranju, bilo u podređivanju izvanjskim zakonitostima profita, dovodi do toga da umjetnost gubi svoju osnovnu crtu, da čuva obećanje sreće.

02 Th. W. Adorno, Negative Dialektik, Franfurt a. M., Suhrkamp 1966. (Usp. Negativna dijalektika, Beograd, BIGZ 1979, prev. Nadežda Čačinovič-

Puhovski i Žarko Puhovski.) 
Riječ je o mogućnosti koja se još uvijek očituju u nastajanju umjetničkih djela koja svojom formom nastoje prekinuti zatvoreni krug perpetuiranja loše sadašnjosti. (U toliko citiranoj rečenici o nemogućnosti pisanja poezije nakon Auschwitza, riječ je upravo o tome koliko je moguće doći do te pozicije nakon strahovitih iskustava.) Odgonetanje pojedinačnih umjetničkih djela, koja to mogu, postaje poslom što ga filozofi ne smiju zanemariti. Želja da se snagom subjekta razbije privid konstitutivne subjektivnosti ne dopušta površna rješenja.

Realni društveni proces ne dovodi se u vezu s filozofijom nekim naknadnim priređivanjem već je on sadržan u logičkoj jezgri filozofije, njezinoj sukrivnji: svaka logika je logika gospodstva. Ali nikada samo to. Stoga: proboj u drukčije nije niti neizbježan niti nemoguć. Negativna dijalektika je samo-odbacivanje metafizike - mišljenje u njoj treba misliti i protiv samoga sebe da bi bilo istinito; samorefleksija i prelaženje u materijalizam izravno su povezani. "Indeks prvenstva objekta je nemoć duha u svim njegovim sudovima kao i, sve do danas, u uređivanju realnosti. Ono negativno, to da duhu s identificiranjem nije uspjelo pomirenje, da je njegovo prvenstvo zakazalo, postaje motor njegovog vlastitog od-čaravanja”.

Ovakav se materijalizam, dakako, u mnogome razlikuje od danas aktualne varijante za koju "nemoć duha", "svijest", "samorefleksija" pripadaju području zabluda, iluzija, budući da je riječ tek o epifenomenima temeljnih materijalnih procesa.

Upustit ću se sada u očitu pogrešku promjene konteksta i u ime iskustava i svjesnosti, makar i iluzorne, materijalni objekt smjestiti u svakodnevicu. Nadnaravno se u mojem odrastanju pojavljivalo vrlo rijetko, nisam imala nikakav vjerski odgoj, preneseno mi je, čini mi se, vrlo malo dubokih predrasuda, samo nešto malo nezadovoljstva i pritužbi spram nekog nedefiniranog usuda. Tu negdje moraju biti korijeni moje navike da govorim sa stvarima, naročito onima koje su mi bile tjelesno bliske, poput čarapa i rublja. Zapravo, ne govorim s njima stalno, nego osjećam dužnost da im uputim nekoliko riječi žaljenja kada sam ih prinuđena baciti.

Ma koliko nastrana bila ova navika, nije jamačno čudnija od drugih načina postupanja sa stvarima, na primjer molitve koje se upućuju nekoj određenoj slici i njezinim čudesnim svojstvima.

Neke su stvari u svakidašnjem životu nečujne, nestaju u uporabi: odatle moji mali rituali. Neke su upadljive i naporne. Postoje odnosi sa stvarima koje moramo shvatiti da bismo se obranili. 
Fetišizam robe, odnosno Marxov stol koji se počinje neobično ponašati, predmet je analize koja nam treba pomoći da shvatimo kako se odnosi između ljudi pretvaraju u odnose među stvarima,

Roba je namijenjena prodaji, ona mora ozbiljiti svoju razmjensku vrijednost. Kupac će dati novac za robu — za neku stvar-zbog njezine uporabne vrijednosti a nju će ozbiljiti tek nakon što je kupnja obavljena. Kupac, dakle, kupuje neku robu zato što od nje očekuje ispunjenje: zbog obećanja uporabne vrijednosti, takoreći, u tuđim riječima, zbog obećanja sreće.

U povijesti tzv. lijeve misli, beskrajno se raspravljalo pitanje kako se može izbjeći učinak postvarenja, odnosno tko može biti subjekt promjena? Danas nam ostaje, ukoliko smo željni promjena, utjecati na empirijski prisutne sugrađane. Jedna od nada, njegovanih na tragu teorija estetike robne proizvodnje, bila je da obećanje sreće, s kojim roba zavodi, i neizbježno razočaranje kada nam ne promijeni život, mogu imati subverzivni učinak. A subverzivni učinak ima i istinsko zadovoljstvo kada se jednom doživi, a ne može se zadržati.

Govor stvari je povezan s rječitošću osjetila. Ona teorijska, vid i sluh, odavno su prestala biti dovoljna, ako su ikada bila. Estetičke operacije nisu nevažne, ukrasne.

Počeci filozofija kulture, na primjer kod Georga Simmela, bili su prije proširenje dohvata filozofije, a ne toliko njezino suočavanje s nečim što joj izmiče, iako se to naslućuje:

"Slika vanjskih stvari za nas je dvoznačna stoga što u vanjskoj prirodi sve može važiti kao povezano, ali i kao odvojeno. Neprekidne preobrazbe tvari i energija dovode svako u odnos sa svakim i sve pojedinosti tvore jedan kozmos. No, s druge strane, predmeti ostaju prognanima u nemilosrdnu razdvojenost prostora, nijednom dijelu materije njegov prostor ne može biti zajednički s nekim drugim, zbiljsko jedinstvo raznolikoga u prostoru ne postoji. I čini se da zbog toga što se isti zahtjev postavlja i međusobno isključivim pojmovima prirodna egzistencija izmiče primjeni tih pojmova uopće." ${ }^{3}$

Claude Levi-Strauss svima nam je otkrio "divlju misao" u kojoj se stvari pojavljuju drugačije:

03 Georg Simmel, “Brücke und Tür”, Der Tag, 15. 9. 2009; hrvatski prijevod K. Miladinov, u G. Simmel, Kontrapunkti kulture, Zagreb 2001, str. 158. 
"Dakako, svojstva pristupačna divljoj misli nisu ona ista koja privlače pozornost znanstvenika. Prema svakom slučaju fizičkom se svijetu pristupa s dvije oprečne strane: jedne, krajnje konkretne, i druge krajnje apstraktne, ili iz kuta osjetilnih kvaliteta ili iz kuta formalnih svojstava. Ali to da su se ta dva puta morala spojiti, barem teoretski, i da nije došlo do naglih promjena u perspektivi, objašnjava da su i jedan i drugi, i nezavisno od jednoga i drugoga u vremenu i prostoru, doveli do dva različita, iako jednako pozitivna znanja: onoga kojemu je temelj pružila teorija osjetilnog i koje i dalje zadovoljava naše osnovne potrebe pomoću vještina civilizacije: poljodjelstva, stočarstva, lončarstva, tkanja, čuvanja i pripremanja hrane itd., koje su se razvile u neolitsko doba, i onoga znanja koje se odmah postavlja na plan pojmljivoga, i iz koje je proizašla suvremena znanost." ${ }^{4}$

Miguel Tamen napisao je pak knjižicu o Prijateljima objekata koji se mogu interpretirati. ${ }^{05}$ Podsjeća nas na porijeklo riječi redukcija (a stvarima se okrećemo upravo kada se borimo protiv redukcije kompleksnosti): redukcija je tehnički pojam kad nešto vidimo kao nešto drugo. Neživi objekti zažive zbog interpretacije, zbog "prijatelja": sve do pitanja života i smrti, na primjer u bizantskoj teologiji i ikonoklazmu, ali problemi se protežu, na primjer, u govorenje o "tijelima”: institucijama, korporacijama.

S umjetničkim djelima oduvijek se događaju neobične stvari. Minimalno svojstvo tih kompleksnih pojava mogli bismo opisati kao očitovanje učinkovitosti nečega što nije stvoreno kao bezostatno funkcionalno. Postoji višak koji se može formulirati kao funkcija nefunkcionalnoga. Takvo stajalište upoznajemo kod pogleda iz drugih disciplina: Jurij Lotman govori o tome kako svaka kultura ima unutrašnje mehanizme za izradu neodređenosti kao dio savladavanja entropije: uvježbava se modeliranje slučajnih procesa. ${ }^{06}$

Antropolozi poput Claude Levi-Straussa i Andre Leroi-Gourhana izlažu logiku koja povezuje mit, umjetnost i konstituiranje znanosti. Takvi su autori pomoć u ispravnom shvaćanju onoga što nas uče Pierre Bourdieu i Terry Eagleton o kontekstu estetičkog suđenja, o ideolo-

04 Claude Levi-Staruss, Divlja misao, pr. J. Milinković, Zagreb 2001, str. 291, 292.

05 Miguel Tamen, Friends of Interpretable Objects, Cambridge (Mass.), 2001.

06 Jurij M. Lotman, Kultura i eksplozija, Alfa, Zagreb 1998. 
giji estetičkoga i tako dalje. Nema mogućnosti suprotstavljanja estetičkoga i političkoga, ali nema ni mogućnosti svođenja estetičkoga na političko. Sa složenošću estetičkoga doživljaja moramo se nositi, čak i onda kada je dojam koji nastaje posvemašnja teorijska nekoherentnost.

Da li je za način na koji umjetnost stvara alternativne, ali opstojne svjetove privida konstitutivna utopijska dimenzija? Ili umjetnost promašujemo i u ovakvome naglašavanju toga da je umjetnost nešto drugo, da je upućivanje na nešto drugo, da je negdje drugdje. I kako mislimo to u materijalističkom ključu?

Terry Eagleton je opetovano pisao protiv takozvanog lošeg ili nezrelog utopizma koje odmah grabi za budućim pa je tako motiviran beskorisnim žudnjama umjesto onima koje bi se možda mogle zadovoljiti. Uvjeren je, ili je barem donedavna bio uvjeren, da tlačiteljske društvene snage ne mogu a da ne proizvedu snagu za pobunu i želju za njom.

Slikâ moguće budućnosti gotovo više nema. Ta vrsta imaginacije bila je dobra za umjetnička djela ionako samo u negativnoj varijanti. Utopijska se dimenzija stoga uvijek iznova traži u dimenziji estetičkoga, u nečemu što bismo čak mogli nazvati estetičkim obratom: ponekad se govori o stalnom izviranju žudnje, ponekad o subverziji, a oblici su vrlo različiti. Adornova očekivanja su vezana uz samozatajni asketizam koji tu žudnju potiskuje minimalističkim proučavanjem formalnoga. Popularna nas je kultura preplavila ikonama pobune, a Fredric Jameson pak izlaže svoju kratku sugestiju

"da se hotimična i nasilna transformacija neuglednog seljačkog predmeta u najsjajniju materijalizaciju boje u uljnom slikarstvu promatra kao utopijska gesta: kao čin kompenzacije koji na kraju proizvodi čitavo novo utopijsko carstvo osjetila ili barem najvišeg od njih, vida, vizualnoga, oka — koje je sada rekonstituirano kao poluautonomni vlastiti prostor - dio neke nove fragmentacije nastajuće osjetilnosti koja replicira specijalizaciju i podjele kapitalističkoga života istovremeno tražeći u takvoj fragmentaciji i očajničku utopijsku kompenzaciju za podjelu." ${ }^{7}$

Antinomije realizma naslov je najnovije knjige Fredrica Jamesona.Što su, dakle, antinomije realizma? Jameson u uvodu sažima svoje sagledavanje problematike, počevši nečim što proglašava "zapažanjem” da

07 Fredric Jameson, "Postmodernism or the Cultural Logic of Late Capitalism”, New Left Review 146, 1984, p. 81. 
fenomen realizma uvijek izmiče analizi, bježeći u dva suprotna pravca: $\mathrm{u}$ rasprave o nastanku romana kao mjesta realističke intencije i u rasprave o nestanku te intencije.

"Realizam je... hibridni pojam u kojemu se epistemologijski zahtjev (za znanjem ili istinom) maskira u estetički ideal s fatalnim posljedicama za obje nesumjerljive dimenzije. Želimo li od realizma socijalnu istinu ili znanje, brzo ćemo vidjeti da je ono što dobivamo ideologija; ukoliko je ono što tražimo ljepota ili estetičko zadovoljstvo, brzo ćemo naći da imamo posla sa zastarjelim stilovima ili pukom dekoracijom (ili pak razbibrigom). Ako je pak povijest ono što tražimo - socijalna povijest ili povijest književnih formi - odmah smo suočeni s pitanjima o korištenju prošlosti pa čak i pristupu prošlosti, pitanjima koja nas, bez obzira koliko na njih nema odgovora, vode daleko izvan književnosti i teorije pa se čini da zahtijevaju suočavanje s našom sadašnjošću. S dijalektičkoga stajališta nije teško vidjeti zašto je to tako. I sociologija i estetika zastarjele su forme mišljenja i istraživanja, utoliko što niti društvo niti ono što se naziva kulturnim ili estetičkim iskustvom u sadašnjem trenutku nisu stabilne supstance koje se mogu empirijski proučavati i filozofski analizirati. Povijest, ako je uopće nešto, poklapa se s dijalektikom te samo može biti problem za koji se predstavlja rješenjem." ${ }^{08}$

$\mathrm{U}$ istinski dijalektičkim istraživanjima detalji se ističu, ne bivaju žrtvovani unaprijed zadanoj shemi. Materijalizam estetike je svijest o ireducibilnosti ljudskoga suočavanja s uvjetima opstanka na jednom zauvijek dana pojmovna određenja, a tome odgovara svijest o nedovršivosti procesa proizvođenja smisla. đI

08 Fredric Jameson, The Antinomies of Realism, London, Verso, 2013. 


\section{Reference}

Th.W. Adorno, Negative Dialektik, Franfurt a. M., Suhrkamp 1966. (v. Negativna dijalektika, Beograd, BIGZ 1979, prev. Nadežda ČačinovičPuhovski i Žarko Puhovski).

Fredric Jameson, "Postmodernism or the Cultural Logic of Late Capitalism", New Left Review 146, 1984.

Fredric Jameson, The Antinomies of Realism, London, Verso, 2013.

Claude Lévi-Strauss, Divlja misao, pr. J. Milinković, Zagreb 2001.

Jurij M. Lotman, Kultura i eksplozija, Alfa, Zagreb 1998.

Jacques Rancière, Aisthesis, Galilée, Pariz 2011.

Georg Simmel, "Brücke und Tür”, Der Tag, 15.9.2009; hrvatski prijevod K.

Miladinov, u G. Simmel, Kontrapunkti kulture, Zagreb 2001.

Miguel Tamen, Friends of Interpretable Objects, Cambridge (Mass.), 2001. 